Володимир Романцов

\title{
ШКОЛА В УКРАЇНІ ЧИ УКРАЇНСЬКА ШКОЛА? ІЗ ДОСВІДУ ДРУГОЇ ПОЛОВИНИ ХХ ст.
}

Рецензія на монографію: Лаврут 0.О. Радянська школа у другій половині XX ст.: вимір України. Слов'янськ: Друкарський двір, 2020. 532 с.

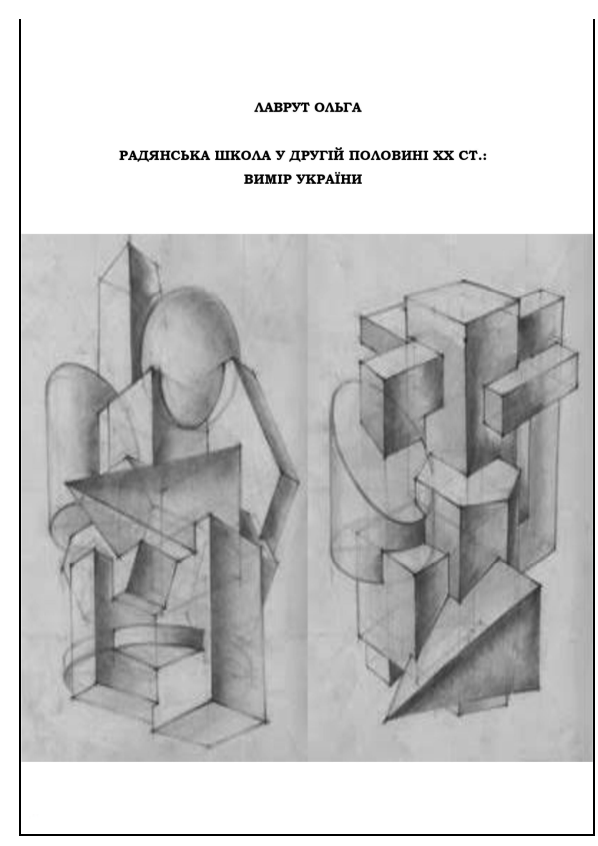

Історична наука, скеровуючи свій погляд у минуле, дає можливість належно оцінити сучасні суспільні проблеми, серед яких важливе місце посідає питання діяльності школи. Пропоноване дослідження має теоретичне і практичне значення, оскільки українська школа потребує уваги - це та інституція, яка не просто дає учням певні знання, а закладає інтелектуальні підвалини розвитку країни, що вимагають постійного оновлення на рівні вимог часу. Реформування школи за нашого часу потребує осмислення всього її попереднього неоднозначного історичного досвіду.

О. Лаврут визначила в якості мети підготовки монографії - з'ясувати місце школи в Українській РСР у другій половині ХХ ст. як «інституту соціологізації дитини у радянському суспільстві», щоб поглибити розуміння його природи. I хоча мова йде про радянську школу в Україні, запропонована тема дуже актуальна. До нашого часу в Українській державі чимало громадян за своїм світоглядом - це радянські люди, які ностальгують за імперською тоталітарною державою, що закономірно прийшла до свого краху три десятиліття тому. Нині в умовах російської гібридної війни вони перебувають під впливом антиукраїнської пропаганди. Щоб протидіяти цьому шкідливому впливу, потрібно усвідомлювати: як радянська школа в Україні ідеологічними міфами деформувала світогляд учнів, яким чином це продовжує сучасна російська пропаганда.

Пропонована науковій спільноті монографія О. Лаврут містить науковий аналіз проблем впливу школи в УРСР на формування радянської людини у другій половині XX ст. Авторка опрацювала великий масив джерел з фондів центральних та обласних державних архівних установ України (близько 200 позицій), документи з археографічних

\footnotetext{
* Романцов Володимир Миколайович - доктор історичних наук, професор, завідувач кафедри історичних дисциплін Маріупольського державного університету (Україна), Заслужений працівник освіти України; ORCID: https://orcid.org/0000-0002-9019-4149; e-mail: romantsov_v@ukr.net
} 
збірників, навчально-методичні матеріали, авторські інтервю, фотоматеріали з приватних колекцій, проаналізувала присвячену обраній темі наукову літературу і на цій основі показала, як у радянському суспільстві компартійне керівництво на різних етапах історії країни поєднувало вирішення реальних освітніх проблем з ідеологічними завданнями комуністичної пропаганди серед молодого покоління та його русифікації, що обумовило суттєву деформацію його світоглядних позицій.

Заслуговує на увагу обрана дослідницею змістова структура праці, оскільки у ній аналізується радянська школа не за стандартною проблемно-хронологічною схемою, а, поєднуючи багатовимірність історичного розвитку. Крім першого розділу, який традиційно присвячений аналізу історіографії, джерельної бази та методології дослідження, у наступних чотирьох розділах окремо розглядаються питання впливу радянської державної політики на школу в різні хронологічні періоди другої половини XX ст., роль цієї інституції відповідно до ідеологічних засад радянського тоталітарного суспільства, антропологічний вимір учительства як соціальної категорії та різні аспекти розвитку стосунків у системі школа - учні - батьки. Така структура монографії видається логічною і надає можливість для глибокого аналізу та цікавих узагальнень досліджуваної проблеми.

О. Лаврут відзначила руйнівні наслідки Другої світової війни для освітньої сфери в Україні, що обумовило необхідність відбудувати мережу навчальних закладів, забезпечити освітню діяльність, що вимагало величезних державних зусиль, але ці заходи супроводжувалися посиленням сталінізму. Дослідниця звернула увагу на неоднозначний характер періоду десталінізації у розвитку школи в Україні, на суперечливий характер реформи 1984 р.

Авторка розглядає соціально-економічні умови функціонування навчальних закладів в УРСР, організацію освітнього процесу та його змістове наповнення. Дослідниця проаналізувала фінансування шкіл, створення їх матеріальної бази для виробничого навчання, яка забезпечувала реалізацію ними політичних рішень компартійних з'їздів, які орієнтували на підготовку людей праці у майстерні, на шкільній ділянці, де учні навчалися працювати на станках, отримували посвідчення про оволодіння додаткових професій (водія, тракториста, механізатора, доярки, друкарки й інших). Протягом періоду, що вивчається, показано візуалізоване прагнення держави задовольнити потреби національних менших, для навчання дітей яких створювалося навчально-методичне забезпечення. Але поступово небагаточисельна кількість таких закладів скорочувалася і перестала існувати. Ситуація змінилася наприкінці 1980-х рр., що було пов’язано з процесами «перебудови» у суспільстві.

Значну увагу приділила О. Лаврут кадровій політиці радянського уряду у школі. Авторка охарактеризувала кількісні показники, які дійсно зросли у зазначений період та якісний склад шкільних педагогів, що зазнав змін із отриманням дипломів у педагогічних училищах, інститутах, університетах. Відзначено, що довгий час залишалася система державного розподілу учителів, адже держава контролювала потребу певного закладу, регіону щодо педагогічних кадрів. Як зазначає авторка, учителі мали не лише навчальне, безпосереднє урочне навантаження, але також виконували багато інших зобов'язань. Головними результатами їх роботи були навчальні та виховні показники. Вагомим для педагогів залишалося моральне заохочення, але й матеріальне теж, що залежало від їх ос- 
вітньої підготовки, місця роботи, кількості дітей у закладах, годин навчального навантаження. Авторка акцентує на антропологічних аспектах життєдіяльності учителів, звернувши увагу на буденність, їх погляди, прагнення, дозвілля, що розкриває повсякдення вчительської спільноти.

Важливе місце у монографії посідає висвітлення питання щодо учнів радянської школи. Дослідниця проаналізувала динаміку змін серед школярів за різними аспектами: кількісними, регіональними, типами місцевості, мовними, розглядаючи вплив демографічних чинників. З'ясовано, що учні, які відвідували початкові та восьмирічні школи були вихідцями із сільської місцевості, середні - у містах. Відзначено, що поступово російська мова навчання витісняла українську. Це продемонстровано у роботі візуально: через таблиці та діаграми. О. Лаврут охарактеризувала механізми творення «радянського учня» шляхом долучення до виховних заходів, формування «правильних» ідеологем суспільства. Не дивлячись на потужний тиск, який відбувався у школі та поза ії межами, учні залишалися дітьми із притаманною їм поведінкою, яка іноді не вписувалася у формалізовані рамки та еталони.

Висвітлюючи процеси розвитку школи в УРСР у другій половині ХХ ст., О. Лаврут зробила обгрунтовані висновки щодо політики комуністичної влади в освітній сфері, відмітивши роль школи як соціальному інституту у радянському суспільстві. Слушно зазначено, що школа виступала засобом досягнення урядових планів, а виконавцями державної політики були вчителі, учні та батьки. При цьому вказано, що радянська школа виконувала як властиві функції щодо навчання учнів та їх соціалізації, а також невластиві «контролера, ідеологічного наставника», готуючи учня «слухняним виконавцем ідей правлячої партії». Заслуговують на увагу пропозиції авторки щодо перспектив подальших студій досліджуваної теми.

Висловлюючи позитивну оцінку монографії О. Лаврут, необхідно зауважити, що, певного редагування заслуговує останній абзац вступу праці, потребують уточнення хронологічні межі поширення радянської ідеологеми «розвинений соціалізм». у першому розділі варто було б продумати систематизацію матеріалів інтерв'ю як одного 3 джерел написання монографії, а, з іншого боку, у питанні застосування усноісторичного методу. Викликає сумнів те, що авторка при висвітленні методології дослідження надто велику увагу (1,5 сторінки тексту) приділила зверненню до радянського наративу у визначенні дефініції «школа».

Загалом, підсумовуючи сказане, можна зробити висновок, що монографія О. Лаврут є завершеною самостійною авторською науковою розробкою і може становити інтерес для істориків, студентів, педагогічних працівників, усіх, хто цікавиться історичним минулим України. 